\title{
AN ANALYSIS OF PHATIC EXPRESSION IN INFORMAL COMMUNICATION AT TIME-OUT TALK AMONG RIAU ISLANDS UNIVERSITY (UNRIKA)STUDENTS
}

\author{
Suswanto Ismadi Megah \\ English Dept. Unrika \\ megah76@yahoo.co.id
}

\begin{abstract}
This study has objective to analyze phatic expression in informal communication at time-out talk among Riau Islands University students, particularly English department students based on the phatic communication of the theory of Malinowski (1923). The data of this study obtained from the students of Riau Islands University (Unrika), particularly English department students. This tudy used 30 subjects. The data obtained during "time-out talk" to have small talk or during their chatting. The data analyzed qualitatively. The data found of the phatic expression consist of particles, there were 14 data found consist of particles, the word phatic form of the repetition there were 10 data found. The influence of the local language there were 5 data found, and influence of the foreign language there were 11 data found. The study concluded that the usage of the particles of the phatic expression used to make communication to strengthen, to preserve, to maintain the communication, more interesting.
\end{abstract}

\section{Keywords: Phatic expression, informal communication and time-out talk}

Abstrak

Penelitian ini memiliki tujuan untuk menganalisis fatis dalam komunikasi informal pada waktu bicara-di antara mahasiswa Universitas Kepulauan Riau, khususnya mahasiswa jurusan Bahasa Inggris didasarkan pada komunikasi phatic dari teori Malinowski (1923). Data penelitian ini diperoleh dari mahasiswa Riau Kepulauan University (Unrika), khususnya mahasiswa jurusan Bahasa Inggris. Studi kita ini digunakan 30 mata pelajaran. Data yang diperoleh selama "time-out bicara" untuk memiliki percakapan kecil atau selama mengobrol mereka. Data dianalisis secara kualitatif. Data yang ditemukan dari fatis terdiri dari partikel, ada 14 data yang ditemukan terdiri dari partikel, kata bentuk phatic pengulangan ada 10 data yang ditemukan. Pengaruh bahasa daerah ada ditemukan 5 data, dan pengaruh bahasa asing ada 11 data yang ditemukan. Studi ini menyimpulkan bahwa penggunaan partikel dari fatis digunakan untuk membuat komunikasi untuk memperkuat, memelihara, menjaga komunikasi, lebih menarik.

Kata kunci: fatis, komunikasi informal dan time-out bicara 


\section{INTRODUCTION}

Language is main tool for communication. Therefore, Holmes (2001: 329) states that language provides a means of encoding a community is knowledge, beliefs, and values, i.e. its culture. In addition, Wardhaugh (1977: 3) says that the language is a system of arbitrary vocal symbol used for human communications. Its definition is employing both the terms system and arbitrary.

Furthermore, Wardhaugh (1977: 219) has states that changes do still continue to occur, but these changes are more typical of the age-grading phenomenon, than of the kinds of changes that occur during the acquisition-process. He stated that old people speak differently from young people and that linguistic generation gaps exist. So that, variation has come the patterns exist for communicating between and within the generations. Old people to young, young to old, fathers to young children, and so on. Second the language of men differs subtly from that of women. Wardhaugh ( 1977: 219) adds that men do not usually use expressions such as it's darling, and women tend not to use pro vanity as extensively as men. So, language used by students in universities.

\section{UNDERLYING THEORY}

Language has a social effect in fulfilling human's need daily. Baskaran (2005:1) Communication is a wide ranging term, but the context which we are referring to is the context of human communication. Human communication has many variables. Thus, language used as the tool of communication has aim to make intimacy among speaker and hearer. Suharyo (2013) states that it is to maintain interaction among speakers and hearers have significances when language used to open communication in intimacy among speakers and hearers, this condition can be mentioned as phatic communication. While Kridalaksana (2007: 14) states that expression in which it is used to start, to maintain, or preserve communication among hearers and speakers. Basically Malinowski, B. (1923) explains that in linguistics, a phatic expression is communication which serves a social function without carrying additional information. So, the term "phatic communion" was coined by anthropologist Bronisław Malinowski in his essay "The Problem of Meaning in Primitive Languages," which appeared in 1923 in The Meaning of 
Meaning by C.K. Ogden and I.A. Richards. The term comes from the Greek "phatos" (spoken, that may be spoken), and from "phanai" (to speak, say).

Besides speech, in the digital world phatic expression can also covers digital interactions. For example, liking someone's social media post can communicate social approval and as a consequence build rapport. While phatic markers and interjection by Leech (1990) mentioned as pragmatic particles, on the other hand Schachter (1985) states as politeness markers so, it is very important in communication.

Furthermore, Malinowski, (1923) scrutinizes that the utterance of a phatic expression is a kind of speech act. Malinowski adds even such apparently "purposeless" communication as polite small talk, like "how are you?" or "have a nice day," even though its content may trivial or irrelevant to the situation, performs the important function of establishing, maintaining, and managing bonds of sociality between participants.

Besides, Kevin (2009) explains about Roman Jakobson's work that 'Phatic' communication is defined differently, and concerns the channel of communication, for instance when one says "I can't hear you, you're breaking up" in the middle of a cell phone conversation. This usage appears, for instance, in research on online communities and microblogging.In speech communication the term means "small talk" (conversation for its own sake) and has also been called "groomingtalking." So, phatic communication is verbal or non-verbal communication that has a social function, such as to start a conversation, greet someone, or say goodbye, rather than an informative function. Learners sometimes find it difficult to recognise phatic communication. For example, a learner may interpret the American English phatic structure 'What's up?' as a question that needs an answer.

In phatic communication, Jumanto (2008:223) describes the function and form phatic communication in the formal and nonformal situation. Besides Jumanto also describes elaboration of the four types of the speakers in power and solidarity as quoted by Brown and Gilman. Jumanto (2008) adds that phatic communication consots of three structures, namely opening, content and closing of the conversation. Each function used to break silence by starting of the communication,. While Leech (1983) small talk in phatic communication to maintain the conversation. In addition, Coupland (2000:2) strictly states small talk considered as phatic 
communication. It consists of gossip, chat, time-out talk. Therefore, in this case, phatic communication used to fill 'space-filling talk'.

Furthermore, Malinowski (1923) states small talk used to empower personal communication. In addition, Richards et. al. (1990) states that safe topic considered as polite topic. Thus, the phatic expression can considered as small talk at time-out talk used to maintain personal communication in informal situation. So, non-formal variety in informalsituation has features such as a. this variety does not have fixed regulation, b, it is used in daily communication, c. it does not have complete grammar and d. it is used to make more intimacy between speaker and hearer.

In this study phatic expression is studied based theory of Malinowski (1923). This study will analyze phatic expression in informal communication at time-out talk among Unrika students, particularly English department students. Unrika is short from University of Riau kepulauan. The students comes from several islands around Indonesia. Therefore, Unrika students come from different first language. Here, it is interesting to study about phatis expression of the students who come from different ethnics in Batam Island. So, they may express differently in their communication. The students of Unrika normally they have small chat or talk during break time at the classroom, canteen, library, etc. therefore, this case is very interesting to be studied.

\section{METHODOLOGY}

The type of this study is descriptive qualitative research. According to Creswell (2003:119) in qualitative research the hypotheses and research questions are often based on theories that the researcher seeks to test. In qualitative research, the use of theory is much more varied. Data collected based sample of population. The population is the whole research data. According to Creswell (2003:156) identify the population in the study. Also state the size of this population, if size can be determined, and the means of identifying individuals in the population. Arikunto (2006:104) states regarding to the determination in the sampling, if the population is less than 100, all will be taken as the population research. Furthermore, if a large number of populations are more than 100, it can be taken between $10 \%-15 \%$ or $20 \%-25 \%$ or more. Therefore, this study used 30 subjects of the English department students of Unrika. 


\section{RESULT}

Data finding and analysis in this part used distributional method. It means that involving researcher used in this study. According to Sudaryanto(1993:15) by using particles, words, phrases as objective of the analyzing of the data. This used to analyze phatic communication in informal communication among Unrika students.

The data found of the phatic expression consist of particles, the word phatic, phatic form of repetition, influence of the local language, and influence of the foreign language. Those will be explained as follows:.

\section{Analysis of particles of the Phatic Expression}

In term of the particles of the phatic expression among English department of Riau Islands University, this study found some of the particles used in the "time out talk". The data found consists of sih, lah, me, la, dong, kek, nak, ah, nih, and euy. Those are seen that some articles influenced by mother tongue of the speakers. The data explained as follows:

\section{a.Particles of $\operatorname{sih}$}

Form of the phatic expression used in informal situation of the "time-out talk". Particles of sih can be seen as follows:

\section{Data 1}

Jangan gitu sih.

It is based on the data 1 above that the used of particle of sih. The phatic expression of the particle of sih is used to strengthen the communication during "time-out talk" among Unrika students in informal communication.

\section{Data 2}

\section{Kemarin sih iya}

It is based on the data 2 above that the used of particle of sih. The phatic expression of the particle of $\operatorname{sih}$ is used to strengthen the communication during "time-out talk" among Unrika 
students in informal communication. This is used to maintain the communication in informal situation.

\section{b. Particles of lah}

This form of the phatic expression used in informal situation of the "time-out talk". Particles of lah can be seen as follows:

\section{Data 3}

\section{Kemana lah}

It is based on the data above that the used of particle of lah. The phatic expression of the particle of lah is used to preserve the communication during "time-out talk" among Unrika students in informal communication. This is used to give alternative of choice.

\section{Data 4}

\section{Kesini dulu lah}

It is based on the data 4 above that the used of particle of lah. The phatic expression of the particle of lah is used to maintain the communication during "time-out talk" among Unrika students in informal communication in requesting of the speaker.

\section{Data 5}

\section{Jangan gitu lah}

It is based on the data 5 above that the used of particle of lah. The phatic expression of the particle of lah is used to maintain the communication during "time-out talk" among Unrika students in informal communication in refusing of the speaker.

\section{c.Particles of $l a$}

This form of the phatic expression used in informal situation of the "time-out talk". Particles of la can be seen as follows: 


\section{Data 6}

\section{Kek mana la}

It is based on the data 6 above that the used of particle of $l a$. The phatic expression of the particle of $l a$ is used to maintain the communication during "time-out talk" among Unrika students in informal communication in asking of the speaker to hearer.

\section{Data 7}

\section{Masuk la}

It is based on the data 7 above that the used of particle of la. The phatic expression of the particle of la is used to preserve the communication during "time-out talk" among Unrika students in informal communication in requesting of the speaker to hearer.

\section{d. Particles of me}

This form of the phatic expression used in informal situation of the "time-out talk". Particles of me can be seen as follows:

\section{Data 8}

\section{Pa nggak ngerti me}

It is based on the data 8 above that the used of particle of me. The phatic expression of the particle of me is used to maintain the communication during "time-out talk" among Unrika students in informal communication in asking of the speaker to hearer.

\section{e. Particles of dong}

This form of the phatic expression used in informal situation of the "time-out talk". Particles of dong can be seen as follows:

\section{Data 9}

\section{Ayo dong}


It is based on the data 9 above that the used of particle of dong. The phatic expression of the particle of dong is used to maintain the communication during "time-out talk" among Unrika students in informal communication in asking of the speaker to hearer.

\section{f. Particles of $k e k$}

Form of the phatic expression used in informal situation of the "time-out talk". Particles of kek can be seen as follows:

\section{Data 10}

\section{Kek mananya?}

It is based on the data 10 above that the used of particle of kek. The phatic expression of the particle of kek is used to maintain the communication during "time-out talk" among Unrika students in informal communication in asking of the speaker to hearer.

\section{g. Particles of Nak}

Form of the phatic expression used in informal situation of the "time-out talk". Particles of nak can be seen as follows:

\section{Data 11}

\section{Nak ambil duit!}

It is based on the data 11 above that the used of particle of nak. The phatic expression of the particle of nak is used to maintain the communication during "time-out talk" among Unrika students in informal communication in asking of the speaker to hearer.

\section{h. Particles of $A h$}

Form of the phatic expression used in informal situation of the "time-out talk". Particles of ah can be seen as follows: 


\section{Data 12}

\section{Ah sudahlah}

It is based on the data 12 above that the used of particle of $a h$. The phatic expression of the particle of $a h$ is used to maintain the communication during "time-out talk" among Unrika students in informal communication in giving opinion of the speaker to hearer.

\section{i. Particles of nih}

Form of the phatic expression used in informal situation of the "time-out talk". Particles of nih can be seen as follows:

\section{Data 13}

\section{Is apalah dia nih}

It is based on the data 13 above that the used of particle of nih. The phatic expression of the particle of nih is used to strengthen in the communication during "time-out talk" among Unrika students in informal communication in refusing of the speaker to hearer.

\section{j. Particles of euy}

Form of the phatic expression used in informal situation of the "time-out talk". Particles of euy can be seen as follows:

\section{Data 14}

\section{Cuaca panas banget euy}

It is based on the data 14 above that the used of particle of euy. The phatic expression of the particle of euy is used to strengthen in the communication during "timeout talk" among Unrika students in informal communication in complsining of the situation around the speaker. 


\section{Analysis of the Repetition of the Phatic Expression}

Repetition of the phatic expression among English department of Riau Islands University, this study found some of the repetition used in the "time out talk". The data found analyzed as follows:

\section{Data 15}

\section{Ayo Jalan-jalan}

It is based on the data 15 above that the the usage of repetition jalan-jalan. The phatic expression of jalan-jalan is used to strengthen the communication during "time-out talk" among Unrika students in informal communication. This is used to remind the hearer.

\section{Data 16}

Ayo-ayo pergi

\section{Data 17}

Yuk-yuk datang kerumah

\section{Data 18}

Yok-yok keluar

\section{Data 19}

\section{Yuk-yuk datang kerumah}

It is based on the data $16,17,18,19$ above that the usage of repetition of ayo-ayo, yukyuk and yok-yok. The phatic expression of the repetition of ayo-ayo, yuk-yuk and yok-yok are used to strengthen the communication during "time-out talk" among Unrika students in informal communication. This is used to command the hearer.

\section{Data 20}

\section{Kapan-kapan kita nonton yuk}


It is based on the data 20 above that the usage of repetition of kapankapan. The phatic expression of the repetition of kapan-kapan is used to strengthen the communication during "time-out talk" among Unrika students in informal communication. This is used to giving information to the hearer.

\section{Data 21}

\section{Apa kamu tengok-tengok!}

It is based on the data 21 above that the usage of repetition of tengok-tengok. The phatic expression of the repetition of tengok-tengok is used to strengthen the communication during "time-out talk" among Unrika students in informal communication. This is used to reminding to the hearer.

\section{Data 22}

\section{Jangan-jangan kamu yang bawa}

It is based on the data 22 above that the usage of repetition of $t$ jangan-jangan. The phatic expression of the repetition of jangan-jangan is used to strengthen the communication during "time-out talk" among Unrika students in informal communication. This is used to hesitating to the hearer.

\section{Data 23}

\section{Dimana-mana selalu ada kamu}

It is based on the data 23 above that the usage of repetition of jangan-jangan. The phatic expression of the repetition of jangan-jangan is used to strengthen the communication during "time-out talk" among Unrika students in informal communication. This is used to hesitating to the hearer.

\section{Data 24}

\section{Ayoklah bareng-bareng beli lipstick}

It is based on the data 24 above that the usage of repetition of bareng-bareng. The phatic expression of the repetition of bareng-bareng is used to strengthen the 
communication during "time-out talk" among Unrika students in informal communication. This is used to requesting to the hearer.

\section{Data 25}

\section{Jangan lama-lama}

\section{Data 26}

\section{Ayo la rame-rame}

It is based on the data 24,25 and 26 above that the usage of repetition of barengbareng, lama-lama and rame-rame. The phatic expression of the repetition of barengbareng, lama-lama and rame-rame are used to strengthen the communication during "timeout talk" among Unrika students in informal communication. This is used to requesting to the hearer.

\section{Analysis of the Local Languages Influences}

In Batam in where various people who came from mostly Indonesian areas. The various ethnics who lived in Batam they spoke Indonesian language but their own local languages still influenced their language. The phatic expression among English department of Riau Islands University this study found some of the local languages influenced their communication used in the "time out talk". The data found analyzed as follows:

\section{Data 27}

\section{Moh moh lah pergi}

It is based on the data 27 above that the usage of local language of moh-moh. It means to ask to go together. It is influenced by Malay language.

\section{Data 28}

\section{Aneh kali awak}

\section{Data 29}

awak nggak suka kali 
It is based on the data 28 and 29 above that the usage of local language of awak. It means "you" to judge the hearers. It is influenced by Bataks language.

\section{Data 30}

\section{kau ini bah keterlaluan}

It is based on the data 30 above that the usage of local language of bah. It means exclamation to judge the hearers. It is influenced by Bataks language.

\section{Data 31}

macemmana mananya

It is based on the data 31 above that the usage of local language of bah. It means asking to the hearer. It is influenced by Malay language.

\section{Influences of Foreign Language (Englsih)}

The influence of the foreign language, particularly English this is due to location of Batam Island which is nearby Sinapuore. In addition, some students work at foreign companies. Therefore, when they communicate, they use some English words. Those are as follows:

\section{Data 32}

\section{Please ambilkan buku}

It is based on the data 32 above that the usage of English of please. It means the speaker wants the hearer to do something. This communication is used to request.

\section{Data 33}

\section{Aku take off jam 5}

It is based on the data 33 above that the usage of English of take off. It means the speaker wants the hearer understand. This communication is used to remind.

\section{Data 34}




\section{Lagi bad mood}

It is based on the data 34 above that the usage of English of bad moodf. It means the speaker wants the hearer understand her feeling. This communication is used to make sympathy.

\section{Data 35}

\section{Sorry ya}

It is based on the data 35 above that the usage of English of bad moodf. It means the speaker wants the hearer to forgive. This communication is used to make apology.

\section{Data 36}

May be ku suka sama dia

It is based on the data 36 above that the usage of English of may be It means the speaker wants the hearer to have a choice. This communication is used to have some prediction.

\section{Data 37}

\section{Ladies nite kemana kita?}

It is based on the data 37 above that the usage of English of ladies nite. It means the speaker wants the hearer to name someone. This communication is used to have intimacy.

\section{Data 38}

Kalau ada quality time yuk

Data 39

Kamu selalu upload foto akulah

Data 40

Nanti print tugas saya ya.

\section{Data 41}




\section{Hunting yuk bareng}

It is based on the data 38, 39, 40, and 41 above that the usage of English. Those mean the speakers want the hearers to request. This communication is used to have a request.

\section{Data 42}

\section{Aku lagi otw}

It is based on the data 42 above that the usage of English of otw. It means the speaker wants the hearer to give information. This communication is used to have an information.

\section{Data 43}

\section{at least ya nggak pa pa}

It is based on the data 43 above that the usage of English of at least. It means the speaker wants the hearer to have condition. This communication is used to have a condition.

\section{CONCLUSION}

The study can be concluded based on the analysis of the data found that the usage of the particles of the phatic expression among English department of Riau Islands University, this study found some of the particles used in the "time out talk". The data found consists of sih, lah, me, la, dong, kek, nak, ah, nih, and euy used to make communication to strengthen, to preserve, to maintain the communication during "time-out talk" among Riau Island University students in informal communication. Besides, the article used to request, to refuse. The repetition of the Phatic Expression used to remind, to command, to hesitate to the hearers.

The usage of the Local Languages Influences of the phatic expression, consist of Malay language because Batam considered as Malay language area. Besides the Bataks language used due to students come from North Sumatra, and Bataks as their original language. So, in Batam in where various people who came from mostly Indonesian areas. The various ethnics who lived in Batam they spoke Indonesian language but their own local 
languages still influenced their language. The phatic expression among English department of Riau Islands University this study found some of the local languages influenced their communication,

The influence of the foreign language, particularly English this is due to location of Batam Island which is nearby Sinapuore. In addition, some students work at foreign companies. Therefore, when they communicate, they use some English words. So, the usage of the phatic expression in the "time out talk" to make communication more interesting.

\section{BIBLIOGRAPHY}

Arikunto, Suharsisni. 2006. Prosedur Penelitian : Suatu Pendekatan Praktik. Jakarta: PT Rineka Cipta.

Creswell,Jhon,W. 2003. Research design Qualitative, Quantitative, and Mixed Methods approaches $2^{\text {nd }}$ edition. London: University of Nebraska, Lincoln.

Holmes, Janet. 2001. An Introduction to Socio Linguistics. London:Longman.

Jumanto. 2008. Komunikasi Fatis di Kalangan Penutur Jati Bahasa Inggris. Semarang: World Pro.

Kridalaksana, Harimurti. 2007. Kelas Kata dalam Bahasa Indonesia. Jakarta: Gramedia Pustaka Utama.

Malinowski, B. (1923) "The Problem of Meaning in Primitive Languages", in: Charles K. Ogden / Ian A. Richards (eds.), The Meaning of Meaning, 146-152, London: Routledge

Malinowski, B. (1923) "The Problem of Meaning in Primitive Languages", in: Charles K. Ogden / Ian A. Richards (eds.), The Meaning of Meaning, 133-135, London: Routledge

Makice, Kevin. 2009. "Phatics and the design of community". Proceedings of the 27th international conference extended abstracts on Human factors in computing systems. Boston, MA, USA.

Sudaryanto. 1993. Metode dan Aneka Teknik Analisis Bahasa: Pengantar Penelitian Wahana Kebudayaan secara Linguistis. Yogyakarta: Duta Wacana University Press.

Suharyo.2013.Ungkapan Fatis Dalam Bahasa Indonesia Ragam Nonformal. Nusa 4.pp.ISSN0216-535X

Wardhaugh, Ronald. 1977. Introduction to Linguistics. Toronto: Mc. Grow Hill Company.

https://pyia.wordpress.com/2010/10/04/ragam-bahasa/ 
CAHAYA PENDIDIKAN, 2(2): 144-160

Desember 2016

ISSN : 1460-4747

https://www.teachingenglish.org.uk/article/phatic-communication 